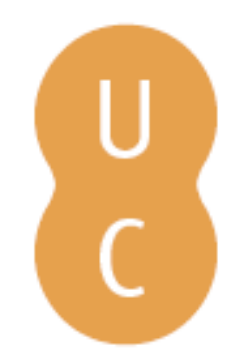

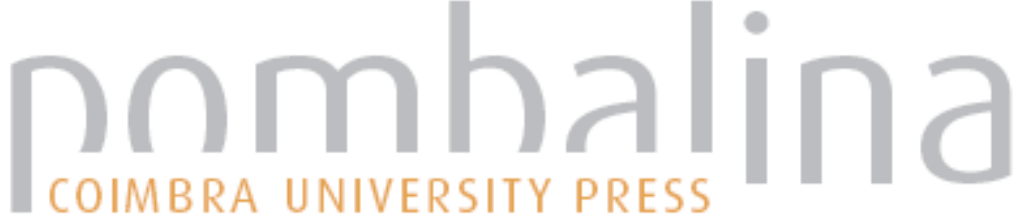

\section{Demétrio de Fáleron e a reinvenção da polis democrática}

Autor(es): Leão, Delfim

Publicado por: Imprensa da Universidade de Coimbra

URL

persistente: URI:http://hdl.handle.net/10316.2/45152

DOI: $\quad$ DOl:https://doi.org/10.14195/978-989-26-1679-7_9

Accessed : $\quad$ 26-Apr-2023 14:48:21

A navegação consulta e descarregamento dos títulos inseridos nas Bibliotecas Digitais UC Digitalis, UC Pombalina e UC Impactum, pressupõem a aceitação plena e sem reservas dos Termos e Condições de Uso destas Bibliotecas Digitais, disponíveis em https://digitalis.uc.pt/pt-pt/termos.

Conforme exposto nos referidos Termos e Condições de Uso, o descarregamento de títulos de acesso restrito requer uma licença válida de autorização devendo o utilizador aceder ao(s) documento(s) a partir de um endereço de IP da instituição detentora da supramencionada licença.

Ao utilizador é apenas permitido o descarregamento para uso pessoal, pelo que o emprego do(s) título(s) descarregado(s) para outro fim, designadamente comercial, carece de autorização do respetivo autor ou editor da obra.

Na medida em que todas as obras da UC Digitalis se encontram protegidas pelo Código do Direito de Autor e Direitos Conexos e demais legislação aplicável, toda a cópia, parcial ou total, deste documento, nos casos em que é legalmente admitida, deverá conter ou fazer-se acompanhar por este aviso.

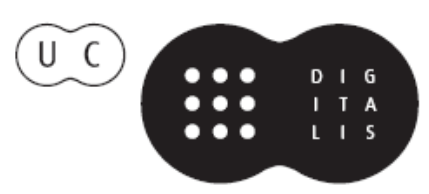



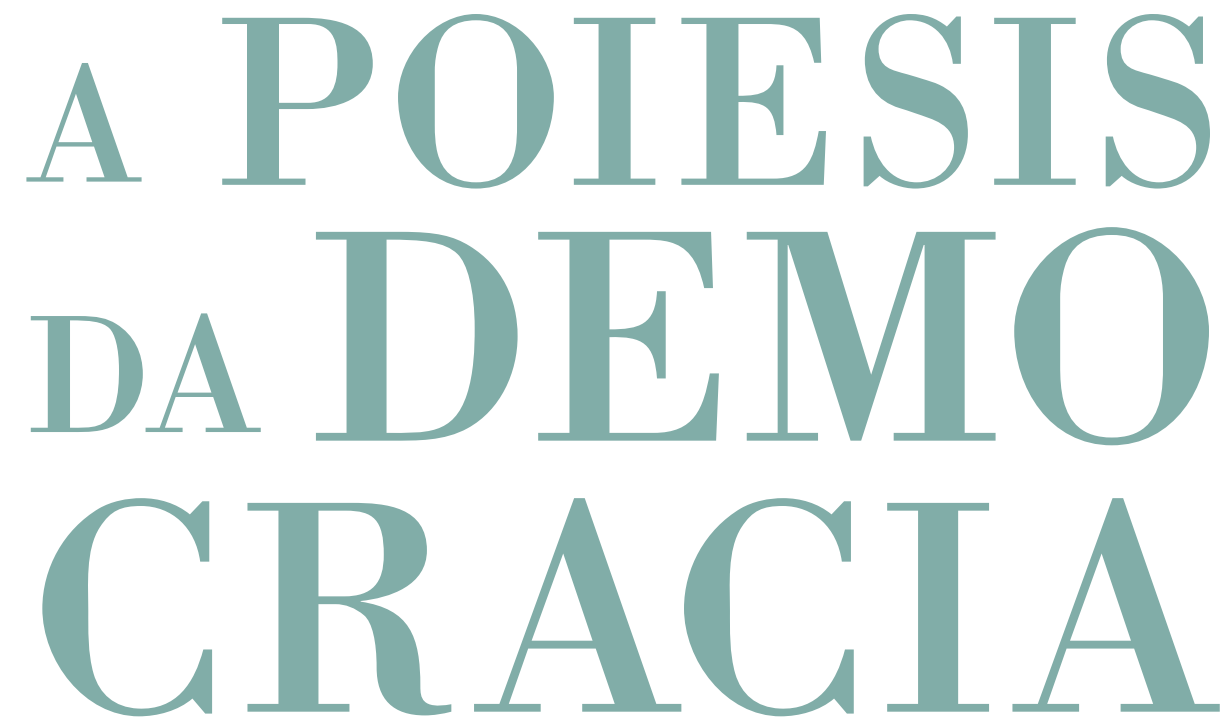

G

Breno Battistin Sebastiani, Delfim Leão,

Lugia Sano, Martinho Soares, Christian Werner

\section{CoimbraCompanions}




\section{Demétrio de Fáleron}

E A REINVENÇÃO DA POLIS DEMOCRÁtiCA

\section{Demetrius OF Phaleron}

AND THE REINVENTION OF THE DEMOCRATIC POLIS

Delfim Leão

UNIVERSIDADE DE COIMBRA

ORCID | 0000-0002-8107-9165 


\section{Resumo}

Em finais do séc. IV, Atenas ficará sob o governo de Demétrio de Fáleron durante dez anos (317-307), ocupando esse período, em termos históricos, o nó de transição entre o final da Atenas clássica (sob forte tutela da Macedónia) e a sua reinvenção como cidade helenística no séc. III. Figura erudita, Demétrio é um produto do Peripatos e ele próprio um discípulo direto de Teofrasto, sendo o seu governo espelho da forma como as antigas cidades-estado eram chamadas a refazer o seu papel político à volta dos Diadochi. A Atenas de Demétrio é, assim, um palco privilegiado para a compreensão destas lutas políticas, de transição entre épocas e regimes. Apesar de curto, trata-se de um período de forte dinâmica constitucional e legislativa, que beneficiou do engenho criativo de Demétrio, o qual é também, provavelmente, o último grande legislador de Atenas. Nesta abordagem, propõe-se o estudo desta figura e deste período, explorando em particular o testemunho de Plutarco, em articulação com outras fontes relevantes para a questão.

\section{Palavras-chave}

Plutarco, Demétrio de Fáleron, legislação, Atenas, Macedónia 


\section{Abstract}

At the end of the Fourth Century, Athens will be under the rule of Demetrius of Phaleron for ten years (317-307), a period that represents, in historical terms, the transition node between the end of classical Athens (under the strong supervision of Macedonia) and its reinvention as Hellenistic city in the Third Century. As a learned figure, Demetrius is a product of the Peripatos and himself a direct disciple of Theophrastus, and his government may be seen as a mirror of the way the former city-states were called upon to reshape their political stance around the Diadochi. Demetrius' Athens is thus a privileged stage for the understanding of these political struggles, and of the transition between periods and regimes. Although short, it is a period of strong constitutional and legislative dynamics, which benefited from the creative ingenuity of Demetrius, who is also probably the last major legislator in Athens. In this approach, we propose the study of this figure and of this period, exploring in particular the testimony of Plutarch, in articulation with other sources relevant to the topic.

\section{Keywords}

Plutarch, Demetrius of Phaleron, legislation, Athens, Macedonia 


\section{CONSIDERAÇÕES PRELIMINARES}

Poderá talvez dizer-se que é, de alguma forma, surpreendente que Plutarco não tenha escrito uma biografia de Demétrio de Fáleron, embora escrevesse biografias sobre estadistas que interagiram de perto com ele, como foi o caso de Fócion e de Demétrio Poliorcetes ${ }^{1}$. Com efeito, a vida de Demétrio de Fáleron fornece elementos bem inspiradores para uma biografia estimulante. $\mathrm{Na}$ casa dos seus vinte e poucos anos, ganhou notoriedade pública no contexto do caso Hárpalo (324), durante o qual ele poderá ter participado na acusação contra Demóstenes, ainda que os detalhes dessa participação não sejam claros². Dois anos mais tarde, depois da batalha de Cránon (322), os Atenienses enviaram legados a Antípatro e a Crátero, com instruções para negociarem os termos da paz (Plutarco, Phoc. 26-27; Diodoro Sículo, 18.1718). Demades, Fócion e Xenócrates encontram-se diretamente referidos entre os negociadores, mas Demétrio fazia provavelmente também parte do grupo, como se pode deduzir de uma citação da obra Sobre o estilo (Eloc. $289=\mathrm{T}$ 12 SOD), trabalho que lhe vem atribuído e em que se diz que, perante a

1 Estudo desenvolvido no âmbito do projeto UID/ELT/00196/2013, financiado pela FCT - Fundação para a Ciência e Tecnologia. Agradeço também o apoio da FAPESP (Procs. 2016/07707-0), da Universidade de São Paulo e da Universidade Federal de São Paulo, na primeira fase da discussão prévia deste programa de investigação. A argumentação agora apresentada corresponde, em termos globais, à versão portuguesa do estudo em inglês feito em Leão 2018, num contexto de discussão e análise mais diretamente virado para questões de direito grego e helenístico. Todas as datas apresentadas ao longo deste trabalho são anteriores à Era cristã.

2 Cf. Diógenes Laércio, 5.75 (= T 1 SOD). SOD é a abreviatura usada para referir os textos relativos à vida e obra (intelectual, política e legislativa) de Demétrio, publicados por Fortenbaugh \& Schütrumpf 2000, segundo o critério de abreviaturas estabelecido pelos próprios autores (p. 10). Ao longo deste estudo, a versão original dos textos usados como fonte (e identificados com a sigla T) será facultada de acordo com a edição de Fortenbaugh \& Schütrumpf. Salvo expressa indicação em contrário, as traduções a partir do original são todas da nossa autoria. 
insolência de Crátero ao receber os embaixadores gregos, ele conseguiu censurá-lo indiretamente através de uma figura de estilo. Os termos de paz celebrados com Antípatro eram bastante duros, implicando uma mudança na constituição e um censo mínimo de 2.000 dracmas como exigência para obter cidadania plena - ainda que essa situação não se tenha prolongado por muito tempo, dado que Antípatro morreu em 319, deixando Poliperconte como seu sucessor indigitado. Este último decidiu equilibrar a rivalidade com outros Diadochi, favorecendo um regresso ao status quo ante em Atenas, restaurando assim a democracia. Apesar de Fócion gozar da reputação de ser "o Bom", não deixava ainda assim de estar profundamente ligado ao governo anterior e, como consequência, acabou sendo condenado à morte, no âmbito das movimentações do novo xadrez político ${ }^{3}$. Demétrio, que estava conotado com ele, sofreu a mesma sentença, mas conseguiu evitar a execução, porque não se encontrava em Atenas no momento em que a condenação foi decidida (Plutarco, Phoc. 35.4-5; Nepos, Phoc. 3.1-2 = T 15A-B SOD). Entretanto, os eventos evoluíram favoravelmente para Demétrio, porque o governo estabelecido em Atenas por Poliperconte não conseguiu expulsar de Muníquia a guarnição que Antípatro lá havia anteriormente estabelecido, ao mesmo tempo que o seu filho Cassandro conseguira recuperar o controlo da cidade e do porto do Pireu. Como consequência, um novo governo foi instalado em Atenas, de acordo com o qual era agora necessário um censo de 1.000 dracmas para se qualificar para a cidadania plena, estabelecendo ainda que a polis deveria ser dirigida por um epimeletes ('superintendente') - um magistrado eleito na Atenas democrática, mas conotado com a ocupação militar no contexto dos governantes macedónios ${ }^{4}$. Demétrio negociou os termos do compromisso, sendo portanto escolhido por Cassandro, em 317, para encabeçar o novo governo como epimeletes

3 Sobre a caracterização essencialmente positiva de Fócion na biografia que dele escreveu Plutarco, vide Leão 2010. Para um estudo comparativo das circunstâncias que envolveram as mortes de Sócrates, Fócion e Catão, vide Trapp 1999. Geiger (1999: 358, argumenta que, embora Plutarco mencione com frequência Platão e Sócrates ao longo do seu trabalho, é apenas num passo da biografia de Fócion (Phoc. 38.5) que descreve e discute diretamente a morte de Sócrates.

4 Fortenbaugh \& Schütrumpf 2000: 49. Mais pormenores em Banfi 2010: 53-63. 
(Diodoro Sículo, 18.74.1-3; IG $\mathrm{II}^{2} 1201$ = T 16A-B SOD), ficando assim revestido da necessária autoridade para preparar novas leis para a cidade ${ }^{5}$.

Testemunhos posteriores descreveram o seu governo como um regresso à democracia ou então, pelo contrário, como uma viragem na direção da tirania, e idêntica disparidade de opiniões pode encontrar-se entre os estudiosos modernos, relativamente à forma como a sua atividade política é avaliada ${ }^{6}$. Mesmo não abordando agora, em pormenor, esse debatido assunto, uma conclusão bastante plausível a retirar consiste em considerar que a sua atividade política e legislativa deve ser muito provavelmente entendida como consequência e também como reflexo dos tempos em que Demétrio viveu e, portanto, como expressão do equilíbrio possível entre o final do sistema da polis (tal como havia sido caracterizado ao longo da Época Arcaica e da Época Clássica) e a preservação de alguma autonomia interna dentro do quadro do efetivo domínio macedónio, como de resto se intuía já a partir da anterior atuação de Fócion 7 . E o facto é que Demétrio foi muito bem sucedido na busca desse propósito, como se pode deduzir do período de paz e de prosperidade que Atenas viveu sob seu domínio - um feito que até mesmo os seus críticos mais ferozes se viam forçados a reconhecer, ainda que, por vezes, desvalorizando-o como simples conquista de um 'vulgar cobrador de impostos orgulhoso de si mesmo' ( $\tau \varepsilon \lambda \omega ́ v \eta \varsigma$

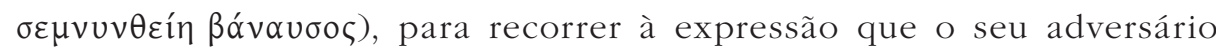
Demócares terá utilizado a propósito dele (registado por Políbio, Hist. 12.13.9 $=\mathrm{T} 89 \mathrm{SOD})$.

5 Gagarin 2000: 348-349, aceita epimeletes como sendo o título atribuído a Demétrio e sustenta que "[the sources] indicate that he certainly enacted some legislation, but we can only determine the substance of two or three laws, and we have no evidence that the legislation was comprehensive". Banfi 2010: 53-63 dá também preferência a epimeletes. Canevaro 2011: 64-65 argumenta, pelo contrário, que, embora o termo epimeletes esteja de acordo com o relato de Diodoro, a palavra em falta no texto de $I G \mathrm{II}^{2}$ 1201, linha 11, será mais provavelmente nomothetes. Esta possibilidade fora já sugerida por Dow \& Travis 1943: 153-156. Vide ainda síntese das várias possibilidades em Fortenbaugh \& Schütrumpf 2000: 51.

6 Tal como Gottschalk 2000: 370, sublinha, "the circumstances of its institution lend some plausibility to either view”. Para uma análise das várias frentes da questão, vide Tracy 2000; Muccioli 2015: 18-38; Faraguna 2018.

7 Para mais pormenores, vide Leão 2012: 85-96. 
Demétrio conseguiu manter o governo durante dez anos, até que um outro Demétrio (filho de Antígono, e mais tarde conhecido como Poliorcetes 'o Sitiador') entrou inesperadamente no Pireu (em 307), anunciando que havia chegado para devolver a liberdade a Atenas. Surpreendido por desenvolvimentos que não soubera antecipar, o Falereu não foi capaz de resistir ao ataque e acabou aceitando um salvo-conduto que lhe permitiu a saída para Tebas, onde permaneceu até à morte de Cassandro (em 297), morte essa que significava para ele também o fim da expectativa de poder vir a retomar o poder em Atenas. Depois disso, foi para Alexandria, onde ajudou Ptolomeu I Soter a conceber as leis para o novo reino e talvez até a idealizar a Biblioteca, embora o seu verdadeiro contributo para esses projetos permaneça envolto em dúvidas e seja bastante discutível. Plutarco afirma que 'Demétrio de Fáleron aconselhou o rei Ptolomeu a adquirir os livros que lidam com a realeza e a liderança, exortando-o à sua leituras: "pois as coisas que os amigos não se atrevem a aconselhar aos seus soberanos, encontravam-se escritas nesses livros"”. Esta afirmação pode sugerir que Plutarco pensou que Demétrio de Fáleron teve um papel ativo na fundação da Biblioteca Alexandrina, embora isso não seja declarado de forma aberta. De facto, a exortação feita a Ptolomeu é muito genérica e pode ser simplesmente um exemplo dos típicos conselhos dados a um monarca9. Mas independentemente do papel que poderia ou não ter tido nesta grande criação do reinado dos Ptolomeus, Demétrio não conseguiu manter a mesma influência sobre o sucessor de Ptolomeu I Soter, a quem dera o conselho de decidir a sucessão em favor de Ptolomeu Keraunos (filho de Eurídice) e não de Ptolomeu II Philadelphos (filho de Berenice). Quando este último chegou ao poder, optou por banir Demétrio para Dióspolis, onde acabaria por morrer pouco depois, mordido por uma

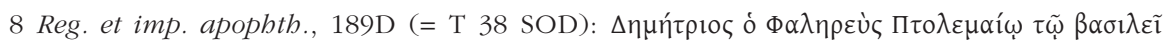

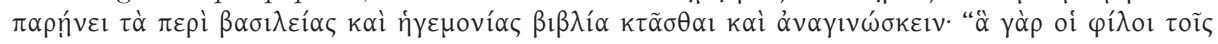

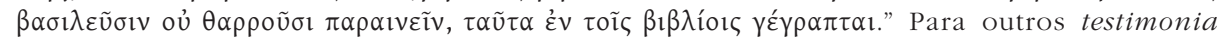
relevantes para a apresentação de Demétrio como responsável pela Biblioteca de Alexandria, vide T 58A-66 SOD.

9 Além disso, este dito é citado entre outros cinco atribuídos a Pisístrato e ainda outros cinco atribuídos a Licurgo, um arranjo simétrico que pode indicar que esta compilação de testemunhos pode simplesmente ser espúria. Esta possibilidade foi ponderada igualmente por Fortenbaugh \& Schütrumpf 2000: 83. 
serpente. Cícero (Rab. Post. $9.23=$ T 42 SOD) diz que ele foi deliberadamente morto, mas Diógenes Laércio (5.78 = T 1 SOD) sugere que se tratou apenas de um acidente e que Demétrio terá morrido durante o sono ${ }^{10}$.

Tomando como um todo esta existência recheada de acontecimentos marcantes e de acentuadas mudanças de sorte, parece justificar-se de facto a tentação de perguntar por que motivo Plutarco não tomou a iniciativa de escrever uma biografia de Demétrio de Fáleron, especialmente considerando que ele decidiu escrever a do adversário Demétrio Poliorcetes. Questionar as opções de Plutarco seria uma operação bastante gratuita, mas analisá-las pode, de facto, ser útil para ter uma melhor compreensão de quais poderiam ter sido as suas motivações para as escolhas que fez. Este não é o momento para abordar essa questão em pormenor, embora a metodologia usada para a discussão deste assunto possa eventualmente ter muito em comum com os tópicos de intertextualidade e intratextualidade, e o modo como Plutarco selecionou e usou as suas fontes. Para ilustrar esse padrão de análise, será suficiente, a título exemplificativo, evocar brevemente o trabalho de Chiara Colonnese, que se dedica precisamente a estudar a seleção de personagens de Plutarco e, mais em específico, as 'vidas não escritas', por assim dizer, de alguns ilustres estadistas gregos ${ }^{11}$. Como a autora sublinha, de forma pertinente, "la raccolta di aneddoti e di detti di un determinato personaggio sembra costituire quasi il primo passo per la formazione di una Vita". Pois embora esse tipo de material seja frequentemente negligenciado pela historiografia, pode no entanto tornar-se muito significativo para o biógrafo, devido à maneira como permite "di restituire un'immagine fresca e immediata dei suoi personaggi, che in tal modo si presentano in prima persona ai lettori"12. A atenção da autora é dedicada essencialmente a Filipe II, a Dionísio I e II, a Demades e a Antígono Monoftalmo, e ainda que Colonnese faça duas alusões muito breves a Demétrio, em ambos os casos o Falereu

10 Gottschalk 2000: 373 tem razão quando afirma que "we can give Philadelphos the benefit of doubt", pois nada tinha já a recear de um ancião como Demétrio. Baseando-se na análise do relato de Diógenes, Sollenberger 2000: 325-326 sustenta com pertinência que Demétrio poderá ter simplesmente cometido suicídio.

11 Colonnese 2007.

12 Colonnese 2007: 100 . 
é lembrado por causa de outros estadistas (Antígono Monoftalmo e Demétrio Poliorcetes) e não por causa de si mesmo ${ }^{13}$.

Não sendo portanto objetivo deste estudo abordar em pormenor a problemática das opções de Plutarco, valerá a pena, ainda assim, recordar a forma como o biógrafo justifica a decisão de retratar a vida de Demétrio Poliorcetes, na abertura da biografia paralela que atribui a essa figura e a Marco António (Demetr. 1.7-8):

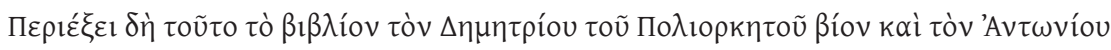

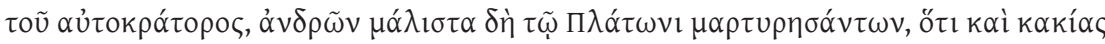

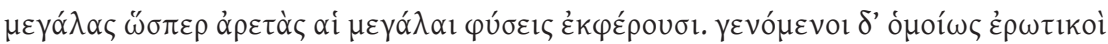

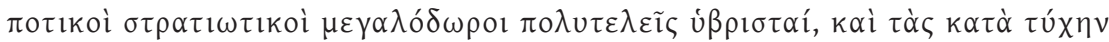

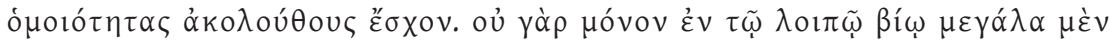

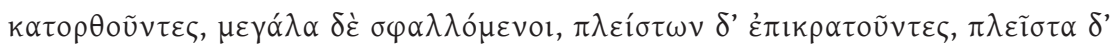

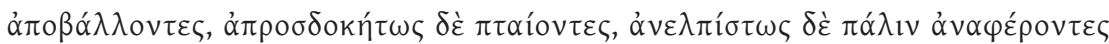

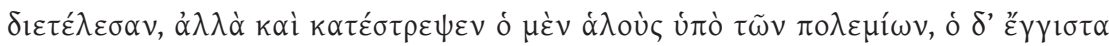

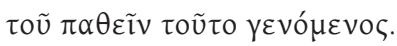

Este livro conterá, portanto, as Vidas de Demétrio 'o Sitiador' e do autocrata [Marco] António, homens que atestaram da maneira mais clara a agudeza de Platão, quando sustenta que as grandes figuras tanto exibem grandes vícios como grandes virtudes. Ambos eram dados ao amor, à bebida, à guerra, à munificência e a excessos extravagantes, e há ainda semelhanças nas suas correspondentes sortes. Com efeito, não só passaram toda a vida granjeando grandes sucessos, como enfrentaram também grandes reveses; obtiveram inúmeras conquistas, mas sofreram ainda inúmeras perdas; caíram de forma inesperada, mas conseguiram levantar-se novamente, contra toda a expectativa. E acabaram também dominados, um capturado pelos inimigos e o outro à beira de idêntica calamidade.

Em termos de convulsões políticas e pessoais, haveria razões suficientes para sustentar que o Falereu poderia substituir o Poliorcetes e fornecer

13 Cf. Colonnese 2007: 79 e 87. 
igualmente um par adequado para Marco António. Por outro lado, embora o Falereu tenha desempenhado um papel importante em Alexandria como intelectual, a sua atividade política foi sobretudo doméstica (i.e. ateniense), faltando-lhe portanto uma dimensão verdadeiramente externa, que de resto não estaria nos seus propósitos cultivar e até seria motivo de crítica da parte dos seus adversários políticos.

Mas à parte esta justificação objetiva, que se prende diretamente com as opções políticas e económicas de Demétrio de Fáleron quando esteve à frente do governo de Atenas, é possível que Plutarco tenha sido sensível a uma outra motivação mais discreta, relativa às características do Falereu enquanto intelectual. Com efeito, no passo antes referido, Plutarco evoca a autoridade de Platão e propõe-se ilustrar, com os exemplos práticos de Demétrio Poliorcetes e de Marco António, o discernimento do filósofo sobre a natureza das grandes figuras e a sua propensão para combinar grandes

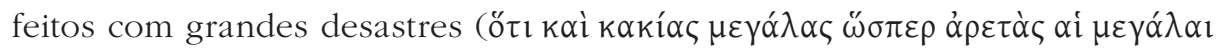

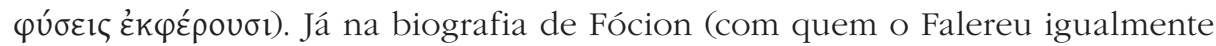
se relacionou, mas neste caso de forma amigável), a imagem da morte de Sócrates (plasmada segundo o modelo de Platão) teve um papel fundamental na interpretação que Plutarco deu ao par Fócion e Catão ${ }^{14}$. Pelo contrário, Demétrio de Fáleron distinguiu-se como aluno e companheiro de Teofrasto, e especialmente como um eminente político e filósofo do Peripatos (vide T 8-11 SOD). Corresponde também ao último nomothetes realmente importante em Atenas, na linha de grandes figuras como Drácon e Sólon, como o próprio gostaria de se representar, inserindo a sua atividade legislativa e política no quadro do longo debate sobre o conceito de patrios politeia, cujas origens, enquanto conceito ideológico e propagandístico, remontavam já ao último quartel do séc. $\mathrm{V}^{15}$.

14 Com efeito, todo o tratamento dado à parte final da existência de Fócion evoca as circunstâncias do julgamento de Sócrates, que Plutarco recorda, sugestivamente, no desfecho da biografia, como exemplo de idêntico patamar de imponderação coletiva (Phoc. 38.5), quando os Atenienses optam por condenar Fócion à morte, da mesma forma que haviam já feito com o filósofo.

15 Vide Canevaro 2011: 65 que sublinha com pertinência a importância de Demétrio de Fáleron para facultar o derradeiro exemplo do que ele chama de "twilight of nomothesia" na Atenas dos inícios da Época Helenística. Faraguna 2015: 154 crê que a possível instituição de nomoplylakes por Demétrio pode ser uma consequência do debate à volta da patrios 
A formação filosófica de Demétrio e a forma como conduziu Atenas durante dez anos (317-307) fazem dele um estudo de caso especial para a análise das possíveis relações entre o ensino filosófico e a atividade política, constituindo esse portanto um tópico frequente na forma como a sua figura é estudada. Essa peculiaridade, porém, parece não ter sido suficientemente cativante para Plutarco, ao menos a ponto de convencer o autor de Queroneia a dedicar-lhe uma biografia. Se tivesse tomado uma opção diferente, é bastante provável que Plutarco representasse para Demétrio o que de facto representa para o legislador ateniense Sólon ou para o espartano Licurgo: a fonte mais importante para a compreensão da sua atividade legal e política, mesmo que nem sempre seja inteiramente fiável como fonte ${ }^{16}$. Ainda assim, o testemunho de Plutarco continua a ser muito importante para a compreensão global da figura de Demétrio de Fáleron, razão pela qual será analisado mais em pormenor ao longo da próxima secção, ainda que combinando as informações que faculta e discute com os dados fornecidos por outras fontes que abordaram esta mesma figura de transição para a Época Helenística e a forma como a polis ateniense se teve de adaptar a um quadro político, económico e militar muito diferente daquele com que contara ao longo da Época Clássica.

\section{Demétrio de FÁleron: um intelectual e estadista num Universo em}

TRANSIÇÃO

Apesar de não ter dedicado uma biografia específica a Demétrio, Plutarco dá provas de estar bastante familiarizado com os desassossegos pessoais, a atividade política e o trabalho intelectual do Falereu, como pode ser claramente deduzido das frequentes referências que lhe faz, ao longo das Vitae e dos Moralia. A maioria das ocorrências encontra-se nas Vitae

politeia. Sobre a emergência do tema da patrios politeia no contexto da Guerra do Peloponeso, em especial no que se refere à interpretação da figura de Drácon e de Sólon, vide Leão 2001: 43-72.

16 Sobre a consistência dos escritos de Plutarco relativamente às leis de Sólon, vide Leão 2016a. Para uma análise sistemática da legislação do estadista ateniense, vide Leão \& Rhodes 2015. 
(catorze) ${ }^{17}$. O número nos Moralia é um pouco mais baixo (nove), mesmo nele incluindo as referências retiradas de obras que não são provavelmente de Plutarco: uma na Consolatio ad Apollonium (104A-B = T 83 SOD) e outra no opúsculo Vitae decem oratorum (850B-C = T 9B SOD), que ainda assim possuem algum interesse, como adiante se verá, no que respeita a informação de natureza ética e factual respeitante a Demétrio. A informação sobre aspetos concretos da existência de Demétrio e sobre outras personalidades e ainda eventos históricos aparecem mais frequentemente nas Vitae do que nos Moralia, sendo que nestes últimos são mais recorrentes as considerações éticas sobre o Falereu e sobre outras figuras a que de alguma forma esteve ligado. Ainda assim e apesar desta predominância relativa de certos temas, não se pode dizer que haja uma clara linha divisória entre as Vitae e os Moralia em termos de informação factual, legal e ética sobre Demétrio.

Plutarco cita-o, com relativa frequência, como sua fonte textual explícita. Assim acontece com oito passos das Vitae que fornecem elementos para a caracterização de Aristides, Demóstenes, Licurgo e Sólon. Os passos que respeitam a Aristides são os mais extensos e facultam igualmente um exemplo claro da forma como Plutarco trabalhava o contributo das suas fontes. Com efeito, na abertura da biografia daquele estadista, Plutarco começa por fazer considerações sobre a tradição de pobreza de Aristides, em relação à qual

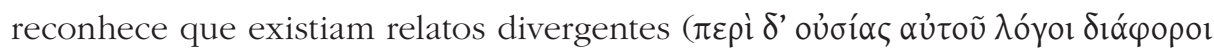

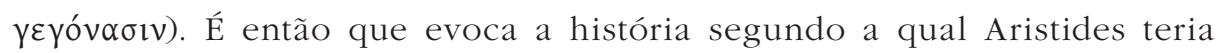
deixado duas filhas solteiras durante um longo período, devido à falta de recursos para as casar convenientemente (Arist. 1.1-4; 6; 7; 8-9 = T 102 SOD), recordando depois mais em pormenor a forma como Demétrio havia argumentado contra essa versão (Arist. 1.2-4; 9):

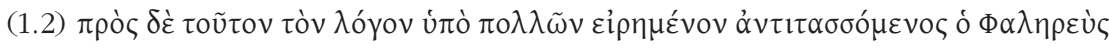

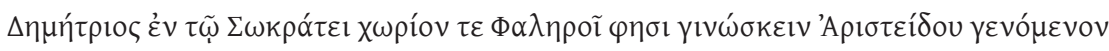

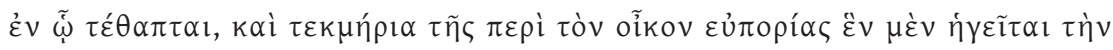

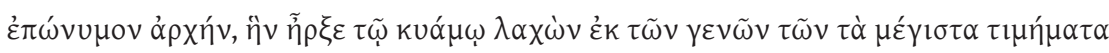

17 Há uma outra referência em Dem. 28.3 (= T 164 SOD), mas deve respeitar provavelmente a Demétrio de Magnésia e não a Demétrio de Fáleron. 


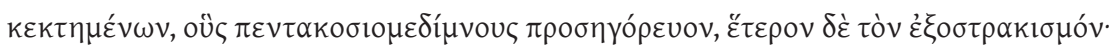

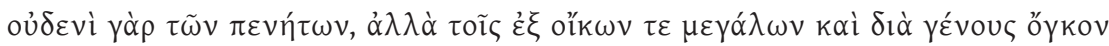

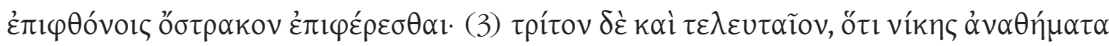

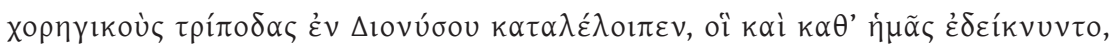

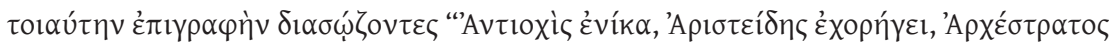

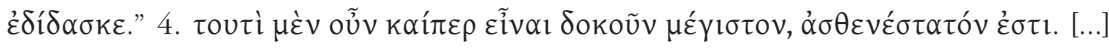

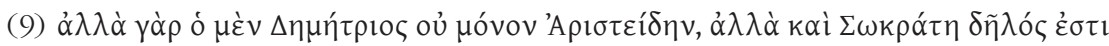

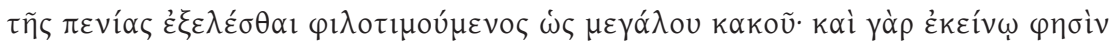

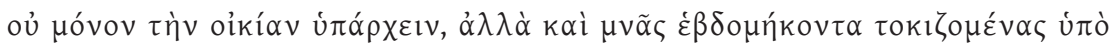

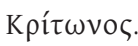

Esta história, que é contada por muitos, vem contrariada por Demétrio de Fáleron, na sua obra Sócrates. Ele diz que conhece a terra em Fáleron que pertenceu a Aristides e onde está sepultado, apresentando as seguintes provas sobre a riqueza da casa de Aristides: primeiro, há a magistratura de arconte epónimo, que é obtida por sorteio entre as famílias do estrato censitário mais elevado, conhecidos como "os das quinhentas medidas" (pentakosiomedimnoi); em segundo lugar, há o ostracismo. Com efeito, não são os pobres que são submetidos ao ostracismo, mas os que pertencem a grandes casas e por isso são objeto de invejas devido ao prestígio da sua família. Em terceiro e último lugar, ele deixou trípodes no templo de Dioniso, dedicadas em reconhecimento da vitória obtida numa coregia. As trípodes, que ainda se podem ver no nosso tempo, preservam a seguinte inscrição: "a (tribo) de Antióquide ganhou; Aristides foi o patrocinador (choregos); Arquéstrato foi o diretor". Acontece, porém, que embora este último argumento pareça ser particularmente forte, na verdade é muito débil. [...] É evidente, no entanto, que Demétrio está empenhado em livrar não apenas Aristides, mas também Sócrates, de um estado de pobreza, como se de um grande mal se tratasse. Com efeito, ele diz a respeito daquele [i.e. Sócrates] que era não apenas dono da casa [onde morava], mas que possuía ainda setenta minas, que haviam sido emprestadas a juros por Críton. 
Embora Plutarco reconheça que os argumentos de Demétrio pareçam fortes, especialmente o último, sustenta no entanto que se revelam efetivamente fracos ( $\varepsilon \dot{\varepsilon} \tau \imath)$ e, na continuação do relato, vai contestá-los um a um. Ao fazê-lo, adota, com efeitos reversos, a mesma abordagem histórico-antiquária usada pela sua fonte, cujas opiniões procura desacreditar. O golpe final na argumentação, por assim dizer, é dado quando avança uma explicação para a perspetiva sustentada pelo Falereu: segundo o biógrafo, Demétrio pretende apenas libertar Aristides e Sócrates do estigma de pobreza, como se fosse um mal que lhes deslustrava a reputação ( $\delta \tilde{\eta} \lambda o ́ \varsigma ~ \varepsilon ̇ \sigma \imath \tau \tilde{\eta} \varsigma ~ \pi \varepsilon v i ́ \alpha \varsigma$

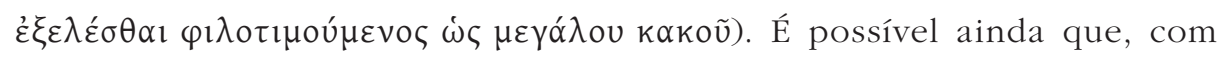
esta afirmação, Plutarco esteja a repreender indiretamente a atração que, segundo algumas fontes, a fama e as honrarias exerceriam sobre Demétrio. E com efeito, o biógrafo faz-lhe mesmo abertamente essa repreensão, num outro ponto dos Moralia (Praec. ger. reip. 820E = T 25B SOD). A referência, no passo em análise, ao trabalho de Demétrio intitulado Sócrates ou Apologia de Sócrates vem confirmada, por outro lado, por Diógenes Laércio $(9.15 ; 9.57 ; 9.37=\mathrm{T} 106,107,108$ SOD), bem como referências que o Falereu fazia a outros filósofos. Também é possível que, alegando que Aristides e Sócrates não eram pessoas pobres, Demétrio estivesse de alguma forma a defender-se de possíveis críticos, no caso de o acusarem de que, com a introdução de um censo de 1.000 dracmas, aquelas duas personalidades famosas dos anos de ouro da democracia não teriam condições para se qualificarem para a cidadania plena ${ }^{18}$.

Em outro passo da mesma biografia (Arist. 5.9-10 = T 103 SOD), Plutarco questiona novamente o relato de Aristides feito por Demétrio, o qual sustentava que o primeiro havia sido arconte-epónimo após a batalha de Plateias, portanto pouco antes de sua morte. Plutarco argumenta, pelo contrário, que Aristides ocupou o cargo imediatamente após a batalha de Maratona, portanto, em 489/8, baseando essa perspetiva na informação

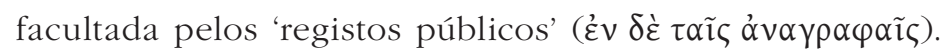


Plutarco volta a mencionar a opinião de Demétrio uma terceira vez na mesma biografia, embora desta vez com uma atitude mista relativamente às informações que são por ele fornecidas (Arist. 27.3-5 = T 104 SOD). Ele alinha o Falereu com Hierónimo de Rodes, o musicólogo Aristóxeno de Tarento e, possivelmente, Aristóteles, os quais haviam todos sustentado que a neta de Aristides, Mirto, coabitava com Sócrates na situação de esposa ( $\Sigma \omega \kappa \rho \alpha ́ \tau \varepsilon \imath \tau \tilde{\omega} \sigma o \varphi \tilde{\omega} \sigma u v o \imath k \tilde{\eta} \sigma \alpha \imath)$. Com efeito, o filósofo, embora fosse já casado, havia-a levado para sua casa, uma vez que ela tinha permanecido viúva (devido à sua pobreza) e passava por necessidades. Plutarco não se preocupa em argumentar diretamente contra essa tradição, dizendo simplesmente que Panécio tinha já respondido adequadamente a esses autores, nos seus capítulos sobre Sócrates. Mais importante, portanto, é o pormenor decorrente do facto de pertencerem ao círculo aristotélico ${ }^{19}$ todos os que, segundo o biógrafo, sustentavam a opinião apresentada. Esta circunstância pode explicar a razão pela qual Plutarco se afigura tão hostil aos pontos de vista de Demétrio nesta biografia em particular: de facto, dá a sensação de estar a reagir de maneira mais ampla contra certas posições defendidas pelos intelectuais do Peripatos $^{20}$. Mesmo assim, Plutarco não parece contrariar Demétrio quando este afirma que, quando ele próprio era legislador $\left(\operatorname{vo\mu }_{0} \theta \tau \tilde{\omega} v\right)$, concedeu à mãe e à tia do neto de Aristides (Lisímaco) um apoio diário de uma dracma, atendendo à situação de extrema necessidade em que viviam ${ }^{21}$. Tal indicação pode ser interpretada simplesmente como uma medida ad hoc, direcionada especificamente para os descendentes de Aristides, mas também já tem sido argumentado que poderia refletir uma regulamentação mais abrangente para apoio aos mais pobres, possivelmente combinada com a reintrodução de um controlo mais apertado

19 Baltussen 2016: 165-166.

20 Sobre a questão das duas mulheres de Sócrates (Mirto e Xantipa), vide também Ateneu, Deipnos. 13.2. 555D-556B (= T 105 SOD).

21 Sobre a importância deste passo para a atribuição do título de nomothetes a Demétrio, vide Banfi 2010: 59-60; Canevaro 2011: 65. No Marmor Parium (B 15-16, Ep. $13=\mathrm{T} 20 \mathrm{~A}$

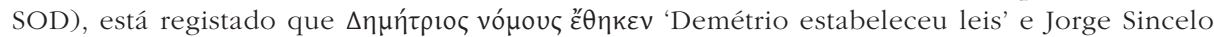
(Ec. Chr. p. 521 = T 20B SOD) afirma que Demétrio foi o terceiro 'legislador' (nomothetes), querendo com isso dizer provavelmente que os dois predecessores haviam sido Drácon e Sólon, como havia sido já sugerido por Dow \& Travis 1943: 156 n. 39. 
do comportamento dos que viviam na ociosidade (argia $)^{22}$. Se fosse realmente esse o caso, esta regulamentação faria lembrar o nomos argias que a tradição atribuía aos tempos de Drácon e de Sólon, ainda que, em boa verdade, o passo em Plutarco não autorize diretamente este raciocínio ${ }^{23}$.

Já na biografia de Demóstenes, Plutarco evoca por três vezes o testemunho de Demétrio, mas agora sempre de forma positiva e mesmo reconhecendo nele uma voz particularmente autorizada. De facto, o biógrafo relembra o Falereu, entre outras fontes, quando está a discutir o brilhantismo de Demóstenes como orador (Dem. 9.1-4 = T 135A SOD) e identifica Demétrio como a fonte expressa de informação sobre um famoso juramento metrificado, que o orador teria proferido: 'E Demétrio afirma que ele proferiu perante o povo, num rasgo de inspiração divina, aquele juramento em verso: "pela terra, pelas fontes, pelos rios, pelas correntes" ${ }^{24}$. Mais adiante, na mesma biografia (Dem.11.1-3 = T 137 SOD), Demétrio é novamente referido como um testemunho autorizado, por afirmar ter ouvido Demóstenes na sua velhice e, assim, estar familiarizado com os seus métodos de treino para melhorar a qualidade da voz, que por natureza era bastante fraca. Plutarco regista a elevada consideração que tem pela opinião

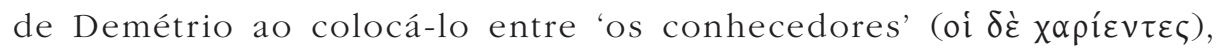
reputando-o, assim, como alguém de bom gosto estético. Plutarco menciona ainda, uma terceira vez, o nome de Demétrio como sua fonte explícita nesta mesma biografia (Dem. 14.1-2 = T 156 SOD), mas é incerta a atribuição da declaração ao Falereu. Embora a opinião expressa seja desfavorável a Demóstenes (que é acusado de falta de coragem na luta e de não ser totalmente imune ao suborno), Plutarco não questiona a sua fonte, provavelmente porque, nesse contexto, pretende enfatizar as qualidades de Fócion sobre as de Demóstenes. De qualquer forma, nestes três passos

22 Banfi 2010: 103-104 e 188.

23 Para um elenco das fontes relativas à atribuição do nomos argias a Drácon e a Sólon, vide Leão \& Rhodes 2015: 109-112.

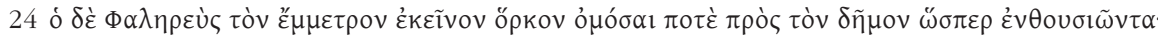

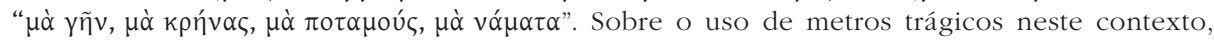
vide Várzeas 2012: 45 n. 25. 
Plutarco está a utilizar o trabalho intelectual de Demétrio, mas sem fazer qualquer referência específica à sua atividade política ou legislativa.

Na biografia de Licurgo (Lyc. 23.1-2 = T 113 SOD), Plutarco menciona a opinião do sofista Hípias e de Filostéfano, que atribuíam a Licurgo um caráter fortemente militar, citando depois Demétrio, o qual apresentava uma visão muito diferente. De facto, o Falereu argumentava, pelo contrário, que

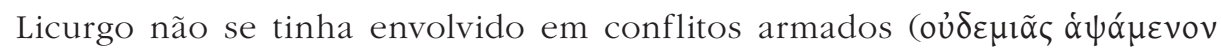
$\pi \circ \lambda \varepsilon \mu 1 \kappa \tilde{\eta} \varsigma \pi \rho \alpha ́ \xi \varepsilon \omega \varsigma)$ e que a constituição espartana havia sido estabelecida

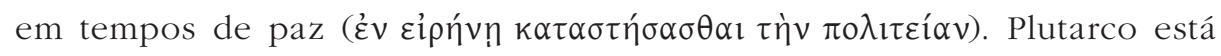
novamente inclinado para concordar com Demétrio, aduzindo por sua vez o exemplo da trégua olímpica, que ele considera ser o trabalho de uma pessoa amena, naturalmente propensa para a paz. Nenhum trabalho específico é referido como fonte, mas não é totalmente improvável que o contexto para esta afirmação possa ter sido a defesa que o próprio Demétrio estivesse a fazer da sua atividade política, que fora marcada precisamente por um período de paz e prosperidade. De facto, Ateneu (Deipnos. $12.60542 \mathrm{~B}=\mathrm{T}$ 43A SOD) regista a opinião de Dúris, que afirma que, durante o governo de Demétrio, as receitas anuais subiram até doze mil talentos, embora lamentasse que ele gastasse mais dinheiro em diversões pessoais do que no apoio ao exército e à administração da cidade. Embora a opinião seja evidentemente hostil a Demétrio, Dúris reconhece, no entanto, a real prosperidade da cidade, cuja justificação se relaciona também com um menor envolvimento em campanhas militares. De resto e segundo Políbio (12.13.9-10 = T 89 SOD), Demétrio mostrava-se orgulhoso também do facto de os alimentos serem abundantes e baratos durante o seu governo, apesar de Demócares o criticar por isso mesmo, dizendo que não passava de mais um sinal da falta de rasgo do estadista, por não ter apoiado outros setores estratégicos ${ }^{25}$.

Plutarco menciona novamente Demétrio como sua fonte explícita na Vida de Sólon, num momento em que o biógrafo está a evocar a legislação sobre o preço das vítimas sacrificiais (Sol. 23.3-4 = T 117 SOD):

25 Vide O'Sullivan 2009: 165-166, que sublinha, com acerto, a prosperidade económica subjacente a esta situação. 


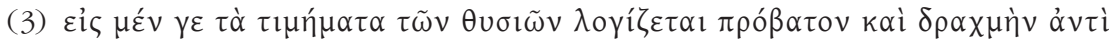

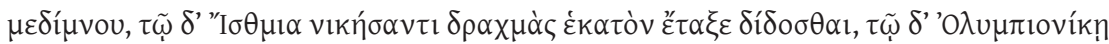

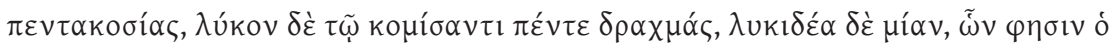

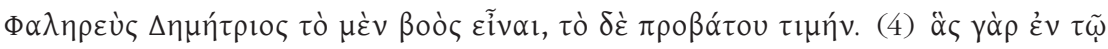

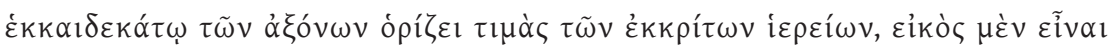

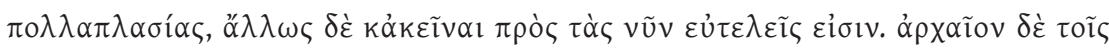

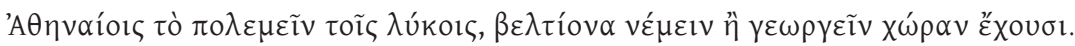

Efetivamente, para o cálculo do valor das vítimas sacrificiais, ele [Sólon] fixou a equivalência de um carneiro ou de uma dracma a um medimno de grão; estabeleceu que se entregasse ao vencedor dos Jogos Ístmicos cem dracmas e ao dos Jogos Olímpicos quinhentas; a quem apanhasse um lobo davam-se cinco dracmas, e a um lobito uma dracma, somas que, segundo Demétrio de Fáleron, correspondiam ao preço de um boi e de um carneiro, respetivamente. Ora os preços das vítimas escolhidas que ele fixa no décimo sexto axon serão possivelmente várias vezes mais elevados do que o corrente, mas ainda assim se mostram inferiores aos praticados agora. É já antiga, entre os Atenienses, a caça aos lobos, pois a sua terra é melhor para a pastagem do que para a agricultura.

Este passo da biografia transmite informações significativas, respeitantes a diversas leis promulgadas por Sólon: regulamentos sobre oferendas votivas, prémios a atribuir aos vencedores em jogos pan-helénicos, recompensas a quem apanhasse um lobo ou uma cria de lobo $^{26}$. O testemunho de Demétrio é aduzido especificamente em conexão com a legislação mencionada, estabelecendo uma correspondência direta entre a compensação atribuída aos que caçavam lobos e o preço das vítimas sacrificiais, no tempo de Sólon, permitindo assim estabelecer uma tábua de comparação de valores praticados em épocas diferentes. Plutarco faculta, ainda, o pormenor muito importante de que Sólon especificava esses preços no décimo sexto axon

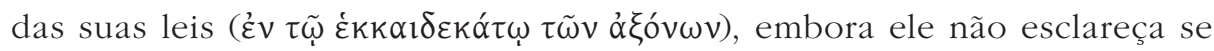

26 Vide Leão \& Rhodes 2015, frgs. 80/2, 81, 89/1a e 92, com comentário. 
essa informação era fornecida pelo próprio Demétrio ou se por qualquer outra fonte. Ambas as possibilidades são aceitáveis, pois há boas razões para admitir que os axones poderiam ser vistos e analisados durante o séc. IV, ainda que apenas fragmentos escassos tenham sobrevivido até ao tempo de Plutarco ${ }^{27}$. Este tipo de material estava, portanto, à disposição de Demétrio, podendo ser assim por ele usado, tanto na sua atividade legislativa como nas reflexões teóricas que escreveu sobre essa matéria. De facto, os títulos das suas obras transmitidos por Diógenes Laércio (5.75-83 = T 1 SOD, especialmente 5.80-81) sugerem fortemente que ele poderá ter usado este tipo de material para esse fim em trabalhos como Sobre a legislação de Atenas (5 livros), Sobre as constituições de Atenas (2 livros), Sobre as leis (1 livro).

Há ainda um outro conjunto de passos (cinco no total), em que Plutarco menciona o Falereu, sendo relativos sobretudo a acontecimentos ligados aos altos e baixos da vida de Demétrio, embora sem esclarecer se será o Falereu a fonte explícita para a informação que está a ser fornecida. De qualquer forma, a possibilidade de identificar essa fonte com Demétrio não deve ser totalmente descartada, especialmente num passo da biografia de Teseu (Thes. 23.1 = T 114 SOD), significativamente o único que não lida com a existência do Falereu, da sua família ou de conhecidos. Com efeito, a informação de que o barco de Teseu havia sido preservado 'até aos tempos

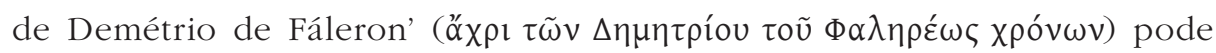
ser simplesmente uma maneira de estabelecer um terminus ad quem geral, globalmente equivalente a dizer agora algo como o último quartel do séc. IV. Mas pode haver aqui também uma sugestão indireta relativa ao envolvimento pessoal de Demétrio na controvérsia intelectual levantada pela questão da renovação contínua do navio de Teseu, à medida que o tempo passava, até ao ponto de se suscitar a discussão sobre se o navio seria ou não ainda o original - questão essa que se tornaria um tema de

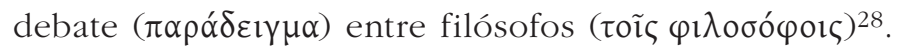

27 Para mais pormenores, vide Leão \& Rhodes 2015: 7-9.

28 No opúsculo sobre as Vidas dos dez oradores (Dec. or. vit. 850B-C = T 9B SOD), informa-se que Demétrio fora aluno de Teofrasto, sendo referido entre outros alunos do Peripatos. Detalhes semelhantes vêm confirmados por várias outras fontes, mas pode ter 
Quanto às quatro outras referências nas Vitae, tratam todas de aspetos da vida e atividade de Demétrio, especialmente antes da chegada ao poder. O mais extenso (Demetr. 8.4-9.3 = T 29 SOD) é o único que aborda a queda do Falereu (em 307), como resultado da ofensiva de Demétrio Poliorcetes, que rapidamente se assenhorou da cidade e - sugere ainda Plutarco também dos corações da maioria dos Atenienses, que o acolheram

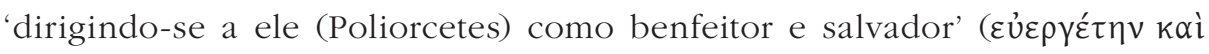
$\sigma \omega \tau \tilde{\eta} \rho \alpha \pi \rho \circ \sigma \alpha \gamma o \rho \varepsilon v ́ o v \tau \varepsilon \varsigma)$. Esta afirmação pode refletir a opinião de uma fonte hostil ao Falereu, ou simplesmente a própria opinião de Plutarco, que em outro ponto da mesma biografia (Demetr. $10.2=\mathrm{T} 18$ SOD), comenta que '[a constituição] havia sido oligárquica de nome, mas monárquica de facto, devido ao poder do Falereu'29. Esta declaração estaria de acordo com o que Plutarco diz sobre os sentimentos que o Falereu alimentou após a sua queda, ao afirmar que ele temia mais os concidadãos do que os inimigos (Demetr. 9.3). Por outro lado, não deixa de ser significativo o facto de, na Vida de Péricles, Plutarco mencionar também, várias vezes, o poder 'monárquico' ou 'aristocrático' de Péricles ${ }^{30}$. No entanto, esta apreciação um tanto depreciativa não impede Plutarco de reconhecer, no final da biografia, que as insinuações em relação ao poder monárquico ou tirânico de Péricles correspondiam, na realidade, à expressão das grandes responsabilidades que tivera na defesa da politeia ${ }^{31}$. Plutarco não chega a

algum significado o facto de (além desta possível alusão indireta à sua base filosófica, na biografia de Teseu) ser apenas nos Moralia que a questão da formação filosófica vem claramente mencionada. Para as fontes relativas à formação filosófica de Demétrio, vide Fortenbaugh \& Schütrumpf 2000: 39-41 (T 8-11 SOD).

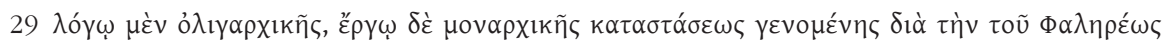

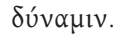

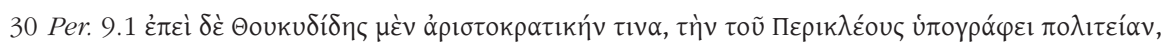

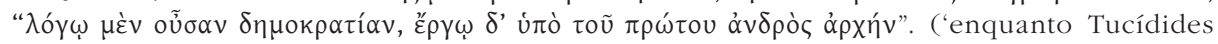
descreve o governo de Péricles como aristocrático - sob o nome de democracia, "na prática era o primeiro dos cidadãos quem governava”.) Tradução de Ferreira \& Rodrigues 2010: 71. O biógrafo cita expressamente Tucídides (2.65.9), fonte citada igualmente nos Praecepta gerendae reipuplicae 802C). Vide ainda Per. 11.1 (no contexto da divisão da polis em duas fações políticas); 16.1-2 (em que cita Tucídides e os poetas cómicos).

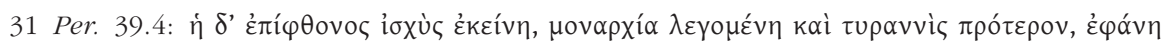

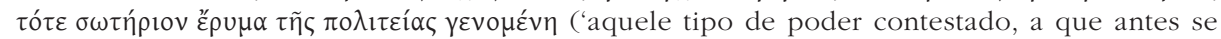
chamava monarquia e tirania, revelou-se então como um baluarte salvador do Estado'). Tradução de Ferreira \& Rodrigues 2010: 148. Tal como Stadter sublinha 1989: 349, "in the grandness of the final sentences, monarchy is no longer a charge to be avoided, but a boast". 
fazer uma declaração semelhante sobre Demétrio de Fáleron, mas a sugestão está realmente presente. Na verdade, a descrição da sua partida para o exílio voluntário está permeada de sentimentos positivos, sugerindo-se assim que o biógrafo poderia ter sido muito duro na sua avaliação global do regime do Falereu. Além disso, Plutarco chega inclusive ao ponto de

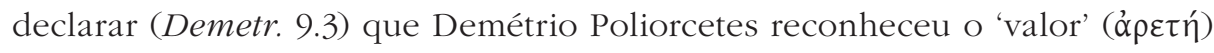
e a 'reputação' ( $\delta o ́ \xi \alpha$ ) de seu adversário, o que pode ser uma maneira implícita de o biógrafo reconhecer o mesmo.

Plutarco regista ainda outras três referências a Demétrio de Fáleron respeitantes a eventos anteriores à instauração do seu regime. Na biografia de Demóstenes (Dem. 28.4 = T 13B SOD), afirma que Himereu, irmão de Demétrio, foi morto (em 322) no contexto da oposição a Antípatro informação confirmada também por Arriano (registado por Fócio, Biblioth. 92.69b34-40 = T 13A SOD). Na biografia de Fócion (Phoc. 35.4-5 = T 15A SOD), Plutarco menciona a ligação de Demétrio a Fócion, bem como a sentença de morte que lhe foi aplicada in absentia (em 318), um detalhe biográfico e político que é confirmado por Nepos (Phoc. 3.1-2 = T 15B SOD), embora este último não mencione explicitamente a condenação de Demétrio à morte quando estava ausente de Atenas.

Essas referências são, no entanto, bastante ambivalentes ou mesmo neutras na forma como consideram a vida e as ações de Demétrio. Mas noutras vezes, Plutarco é inequívoco nas críticas que faz ao Falereu, como acontece num passo dos Praecepta gerendae reipublicae, em que ele censura o gosto de Demétrio por honrarias (Praec. ger. reip. $820 \mathrm{E}=\mathrm{T} 25 \mathrm{~B}$ SOD):

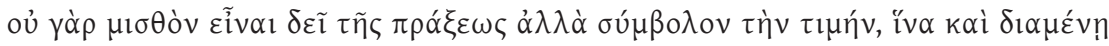

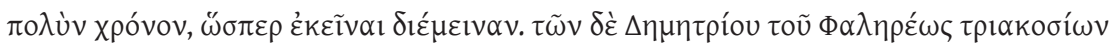

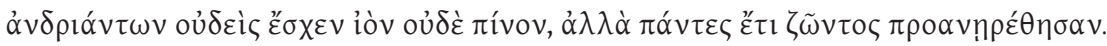

Relativamente a Demétrio, Pausânias (1.25.6 = T 17 SOD) vê o seu governo como uma manifestação de tirania com o apoio de Cassandro. O'Sullivan (2009), 42, interpreta corretamente este juízo como expressão da proeminência (e portanto epimeleia) de Demétrio e não como uma afirmação de alcance estritamente constitucional. 
Ora a honra deve ser concedida não em pagamento por uma ação realizada, mas antes como um símbolo, para que também possa perdurar durante muito tempo, como perduraram as honras mencionadas anteriormente. Das trezentas estátuas de Demétrio de Fáleron, não houve uma única que ficasse enferrujada ou suja; pelo contrário, foram todas deitadas por terra durante o seu tempo de vida.

Plutarco não está a argumentar contra o direito de receber reconhecimento público, mas antes em favor da moderação: assim, uma inscrição ou um decreto honorário seriam o suficiente para uma pessoa sensata, que não sentiria a necessidade de ter uma estátua que lhe fosse dedicada. As considerações éticas do biógrafo movem-se, portanto, em torno da correlação equilibrada de 'honra' ( $\tau \iota \mu \eta ́)$ e do tipo de 'pagamento' ( $\mu \iota \theta$ ós) que pode estimular. Assim, esta declaração dirige-se provavelmente contra uma aspiração desproporcionada e megalómana por distinções públicas que Demétrio teria cultivado, fazendo erigir centenas de estátuas em sua honra por toda a Ática. Na verdade, de acordo com as fontes (T 24A-25C SOD), o número de estátuas de bronze oscilaria entre trezentas e mil e quinhentas. Estes dados ajudaram a fomentar a ideia de que Demétrio teria tido um comportamento perdulário, mas é um tipo de informação que está longe de ser segura ou confirmada, em termos históricos ${ }^{32}$.

Não obstante estas críticas, em vários passos Plutarco menciona também Demétrio como um exemplum de ascensão e queda, que pode consequentemente iluminar os outros, seja quando o próprio Demétrio é a fonte de informação ou quando são outros a evocar a sua figura. Essas referências são caracterizadas por uma motivação claramente ética e, portanto, não é surpreendente que todas elas ocorram nos Moralia. De facto, no De exilio $(601 \mathrm{~F}-602 \mathrm{~A}=\mathrm{T} 35$ SOD), Plutarco menciona Demétrio como um

32 Conforme Tracy 2000: 334, oportunamente sublinha: "if this really happened, and in the huge numbers reported, the stone bases of these statues would surely have been reused and some of them at least should have survived. Yet, as we shall see, not a single one has with certainty." Na Consolatio ad Apollonium, Plutarco combina a tradição sobre a natureza autocrática do regime de Demétrio e a sua apetência por honrarias com passos retirados da tragédia de Eurípides, fazendo do conjunto uma declaração de natureza ética (Cons. ad Apoll. 104A-B = T 83 SOD). 
paradigma construtivo, para mostrar que é possível suportar a dura experiência do exílio e ser novamente bem sucedido, conforme aconteceu quando se deslocou para Alexandria, a convite de Ptolomeu. De facto, como já foi observado nas observações preliminares (supra secção 1), depois do seu exílio voluntário em Tebas, Demétrio viajou para Alexandria, onde terá prestado assistência a Ptolomeu I Soter, tendo talvez mesmo tido um papel ativo na fundação da Biblioteca de Alexandrina, embora isso não seja declarado abertamente por Plutarco.

A mesma dimensão paradigmática pode ser detetada num passo do opúsculo Quomodo adulator ab amico internoscatur (69C-D = T 32 SOD),

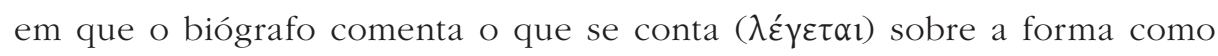
o Falereu apreciou uma palavra de reconforto da parte dos amigos, na altura em que fora banido da sua terra para viver junto de Tebas, na obscuridade. No De tuenda sanitate praecepta (135C = T 67 SOD), Plutarco compara pares de figuras (Xenócrates e Fócion, Teofrasto e Demétrio) para ilustrar a ideia de que dedicar-se ao imobilismo não é melhor para a saúde do que mostrar-se empenhado numa atividade, especialmente se for uma atividade política.

Nos Praecepta gerendae reipublicae (818C-D = T 50 SOD), Plutarco alinha Demétrio juntamente com Péricles e Címon, cujos 'atos políticos' (politeumata33) são apresentados como exemplos de medidas que envolviam uma distribuição coletiva de benefícios:

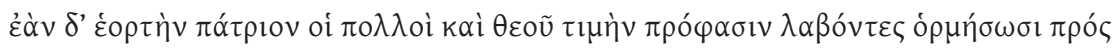

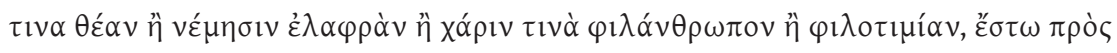

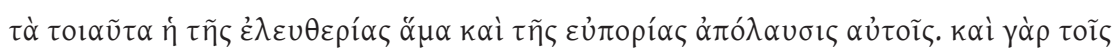

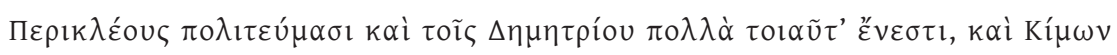

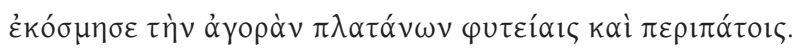

E assim, se a multidão encontrar um motivo de celebração numa festa tradicional em honra de um deus e se inclinar para algum espetáculo ou

33 Sobre o amplo espectro de significados cobertos pelo termo politeuma na obra de Plutarco, vide Leão: $2016 b$. 
para uma pequena distribuição ou para uma benesse pública ou munificência privada, deve ser-lhes permitido gozar dessa liberdade e ter recursos para o fazer. Afinal, há muitas coisas desse tipo entre os atos políticos de Péricles e também entre os de Demétrio; de resto, Címon também adornou a Ágora, com a plantação de plátanos e com zonas de passeio.

A seleção de personalidades feita por Plutarco é curiosa e, à primeira vista, mesmo surpreendente, porque o Falereu aparece enumerado entre figuras bem conhecidas dos tempos de ouro da Atenas democrática - uma opção difícil de conciliar inteiramente com a ideia de que Plutarco via Demétrio como um simples autocrata. Como já antes foi observado, ao discutir a maneira como Plutarco caracterizara o governo do Falereu (Demetr. 10.2 = T 18 SOD), o objetivo do biógrafo consistirá mais em sublinhar que Péricles e Demétrio eram líderes poderosos e carismáticos (e não tanto autocratas em sentido restrito), além de serem igualmente propensos a larguezas públicas, a fim de garantir o favor popular. Com efeito, Demócares (citado por Políbio, 12.13.10-12 = T 89 SOD) imputa ao seu adversário político Demétrio uma política de panem et circences, mas Cícero argumenta (Off. 2.17.60 = T 110 SOD), pelo contrário, que Demétrio desaprovava os custos excessivos aplicados por Péricles na construção dos Propileus. Além disso, a ideia de que ele era bastante moderado em termos de construções públicas parece ser consistentemente confirmada por outras fontes (Diógenes Laércio, 5.75; Vitrúvio, De $\operatorname{arch}$. 7, praef. 16-17 = respetivamente T 1 e 54 SOD) 34 .

No passo dos Praecepta gerendae reipublicae acima citado, Plutarco refere festas em honra dos deuses, espetáculos públicos e atos privados de munificência, mas não especifica em que tipo de manifestações de liberalidade pública Demétrio pode ter estado diretamente envolvido. O seu adversário Demócares acusava-o de haver patrocinado, com fundos públicos, durante o seu arcontado em 308, festas perdulárias que apenas patenteavam a sua subjugação simbólica a Cassandro (opinião registada em Políbio, 12.13.11:

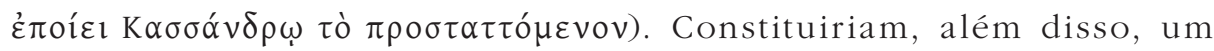

34 Vide observações de O'Sullivan 2009: 128; Banfi 2010: 188-189. 
estratagema político para desmotivar as pessoas de reagirem contra o domínio macedónio ${ }^{35}$.

Para além desta acrimónia política, a real natureza da legislação de Demétrio no que diz respeito ao uso de fundos públicos e aos contributos privados para festivais e outros serviços continua a ser motivo de aceso debate. Discute-se, em particular, em que medida ele terá sido responsável pela reestruturação do sistema das liturgias e, especialmente, pela transformação do sistema corégico, ao criar um novo magistrado responsável pela organização dos festivais dramáticos, o agonothetes ${ }^{36}$. Embora não seja este o momento para discutir esta controversa questão em profundidade, será pertinente ainda assim evocar mais alguns pormenores, na medida em que há um texto de Plutarco que vem geralmente referido como argumento importante para a análise do tema da reforma do sistema litúrgico. Trata-se de um passo do opúsculo De gloria Atheniensium (349A-B = T 115 SOD), onde se criticam os recursos gastos pelos Atenienses na promoção de concursos dramáticos (ou pelo menos na celebração da vitória nesses concursos), por comparação com o escasso investimento na luta contra os Bárbaros e na defesa da liberdade democrática. Depois desta declaração mais genérica, Plutarco aduz explicitamente a opinião de Demétrio, embora não especifique a obra em que seria expressa (349B):

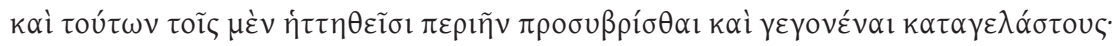

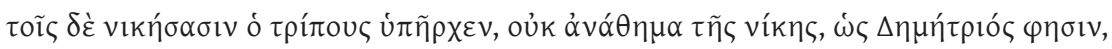

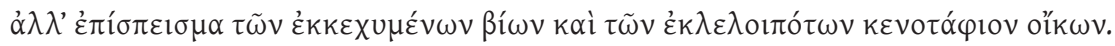

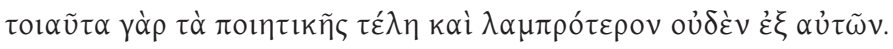

35 Fortenbaugh \& Schütrumpf 2000: 171.

36 Como exemplo da disparidade de perspetivas na forma de interpretar esta questão, O'Sullivan 2009: 168-185 argumenta que a introdução da agonothesia ocorreu em 307/6, acompanhando a 'restauração' do regime democrático, a seguir à deposição de Demétrio; pelo contrário, Banfi 2010: 175-181 recorre basicamente às mesmas fontes de informação para sustentar que Demétrio tinha bons motivos para redefinir (ou mesmo eliminar) o sistema corégico, tendo em consideração os riscos que implicava para a estabilidade social - uma ameaça que havia sido já apontada por Aristóteles (Pol. 1309a11-19). Relativamente à possível influência dos ensinamentos de Aristóteles e de Teofrasto sobre Demétrio, no que a esta matéria em particular diz respeito, vide Gottschalk 2000: 378, com referências bibliográficas (n. 30). 
Quanto aos que entre eles [i.e. os choregoi] eram vencidos, nada mais lhes restava senão serem objeto de desprezo e de ridículo; mas para os que saíam vencedores havia a trípode, que constituía, como Demétrio diz, não uma oferta votiva para celebrar a sua vitória, mas antes uma última libação aos meios de sobrevivência derramados e um memorial vazio aos seus lares falidos. Na verdade, tais foram as recompensas da arte poética e nenhum outro esplendor maior delas proveio.

Esta crítica aos monumentos corégicos tem sido interpretada como uma prova de que Demétrio foi responsável pela criação da agonothesia, a qual estaria ligada à abolição do sistema corégico tradicional: em vez de deixar a um cidadão rico a obrigação de cobrir as despesas dos festivais dramáticos, a nomeação de um agonothetes oficial (que recebia financiamento público para esta atividade) tornaria o demos no verdadeiro choregos dessas produções artísticas e no beneficiário da visibilidade que lhes vinha associada ${ }^{37}$. É um facto que a atribuição a Demétrio desta inovação não é claramente comprovada por nenhuma fonte antiga e que a primeira referência epigráfica a um agonothetes aparece apenas numa inscrição de 307/6 (IG II ${ }^{2}$ 3073), ou seja, logo após ao derrube do regime de Demétrio e da 'restauração' da democracia por Poliorcetes. Ainda assim, há que reconhecer que esta informação epigráfica é bastante ambivalente: com efeito, pode simplesmente demonstrar que a agonothesia foi uma das medidas de Demétrio que foram preservadas na ordem emergente e não que se tratava de uma criação do novo regime - possibilidade aliás bastante improvável, tendo em consideração que apenas alguns meses haviam passado desde a queda do Falereu, que o novo governo ainda era instável e que uma reforma do sistema corégico não estaria, portanto, entre as prioridades mais óbvias da nova administração ${ }^{38}$.

\footnotetext{
37 O'Sullivan 2009: 178-177 argumenta que a hostilidade de Demétrio não se direcionava contra o sistema litúrgico em geral, mas antes contra os excessos dos choregoi na construção dos monumentos nos quais se colocava a trípode da vitória. Wilson \& Csapo 2012: 301 partilham a mesma opinião.

38 Neste sentido se exprime Banfi 2010: 179. Wilson \& Csapo 2012: 301-302 reconhecem que há boas razões para atribuir a Demétrio a criação da agonothesia, mas sustentam que "the shift from chorêgia to agônothesia was a prolonged, tumultuous, and complex process" (p. 317), que se terá iniciado possivelmente antes do governo de Demétrio (portanto já no tempo de Fócion), tendo sido concluído somente depois da queda do seu regime, com a
} 
Por outro lado, Demétrio havia implementado medidas sociais e fiscais com o objetivo de controlar a dissipação da riqueza, fosse ela causada por delapidação pública ou por sumptuosidade privada (cf. Cicero, Leg. 2.25.6227.67 = T 53 SOD), de forma que a introdução da agonothesia estaria de acordo com o espírito geral que teria motivado aquelas regulamentações.

\section{CONSIDERAÇÕES FINAIS}

A análise proposta começou por partir de uma indagação sobre as hipotéticas causas que poderiam ter levado Plutarco a decidir não escrever a biografia de Demétrio de Fáleron, atendendo a que escrevera as Vidas de duas figuras que estiveram a ele ligadas, seja por proximidade (Fócion) seja por oposição (Demétrio Poliorcetes), e ainda que a vida do Falereu fora marcada por inúmeras reviravoltas da sorte e pelos momentos de claridade e de sombra que atraíram Plutarco em outras personalidades. Talvez o facto de Demétrio ser um aluno de Teofrasto e um representante da intelectualidade peripatética, que dispensara algumas críticas à figura de Sócrates, possa ter desmotivado o 'platónico' Plutarco de lhe dar maior atenção. Fosse por esta razão ou por qualquer outra, o certo é que o biógrafo de Queroneia mostra, em todo o caso, estar muito familiarizado com a vida e obra de Demétrio. Com efeito, Plutarco menciona mais de vinte vezes o trabalho, a atividade ou mesmo o exemplum de Demétrio, tanto como fonte de informação sobre outras figuras e eventos, quanto como uma personalidade estimulante por si mesma. Dos contextos em que a presença de Demétrio pode ser detetada, emerge a figura multifacetada do intelectual, do político e do legislador e, finalmente, a do expatriado caído em desgraça, que, no entanto, conseguiu recuperar vitalidade e notável influência na corte dos Ptolomeus. É deste mosaico variado de experiências e de sensações que se alimenta, de resto, a imagem deste exemplo vivo de estadista e filósofo,

restauração democrática de 307. Na biografia de Fócion, Plutarco (Pho. 31.1-2) afirma que Nicanor, um enviado de Cassandro, fora convencido por Fócion a atuar como agonothetes em Atenas, numa estratégia que visava tornar o domínio macedónio menos pesado para os Atenienses. 
que não foi nem um verdadeiro democrata (ao menos nos termos esperados para a Época Clássica, apesar da insistente comparação com Péricles, nem sempre positiva), nem tão pouco o tirano autocrata retratado por algumas fontes a ele hostis. Tal como antes dele Fócion (de forma mais drástica e conhecendo um final mais violento), a atuação de Demétrio de Fáleron (provavelmente o último grande nomothetes ateniense) espelha, sobretudo, as limitações e contradições de uma grande polis como Atenas, que tinha de aprender a reinventar-se no âmbito do quadro de efetivo domínio macedónio, pesem embora as apregoadas tentativas de 'restauração' da democracia e da verdadeira 'constituição ancestral', nas diferentes expressões ideológicas e propagandísticas do tema da patrios politeia.

\section{Bibliografia CitadA}

Baltussen, H. (2016), The Peripatetics. Aristotle's Heirs 322 BCE - 200 CE. London.

Banfi, A. (2010), Sovranità della legge. La legislazione di Demetrio del Falero ad Atene (317-307 a.C.). Milano.

Canevaro, M. (2011), "The Twilight of nomothesia: Legislation in Early-Hellenistic Athens (322-301)", Dike 14: 55-85.

Colonnese, C. (2007), Le scelte di Plutarco. Le vite non scritte di greci illustri. Roma.

Dow, S. \& Travis, A. H. (1943), "Demetrios of Phaleron and his Lawgiving", Hesperia 12: 144-165.

Faraguna, M. (2015), "I nomophylakes tra utopia e realtà istituzionale delle città greche", Politica Antica 5: 141-159.

Faraguna, M. (2018), "Demetrius of Phalerum and Fourth-Century Athenian Society. Response to Delfim Leão”, in G. Thür, U. Yiftach \& R. Zelnick-Abramovitz (herausg.) Symposion 2017. Wien, [pp. no prelo]

Ferreira, A. M. \& Rodrigues, A. R. (2010), Plutarco. Vidas Paralelas: Péricles e Fábio Máximo. Tradução do Grego, introdução e notas. Coimbra.

Fortenbaugh, W. W. \& Schütrumpf, E. (2000), Demetrius of Phalerum. Text, Translation and Discussion. Rutgers University Studies in Classical Humamities, vol. IX. New Brunswick.

Gagarin, M. (2000), "The legislation of Demetrius of Phalerum and the Transformation of Athenian Law", in W. W. Fortenbaugh \& E. Schütrumpf (eds.), Demetrius of Phalerum. Text, Translation and Discussion. Rutgers University Studies in Classical Humamities, vol. IX. New Brunswick, 347-365.

Geiger, J. (1999), "Plato, Plutarch and the Death of Socrates and of Cato", in A. Pérez Jiménez, J. García López \& R. María Aguilar (eds.), Plutarco, Platón y Aristóteles. Madrid, 357-364.

Gottschalk, H. B. (2000), "Demetrius of Phalerum: a Politician among Philosophers and a Philosopher among Politicians", in W. W. Fortenbaugh \& E. Schütrumpf, Demetrius of Phalerum. Text, Translation and Discussion. Rutgers University Studies in Classical Humamities, vol. IX. New Brunswick, 367-380. 


\section{DELFIM LEÃO}

Leão, D. F. (2001), Sólon. Ética e política. Lisboa.

Leão, D. F. (2010), "Tyche, Kairos et Chronos dans le Phocion de Plutarque", in F. Frazier \& D. Leão (eds.): Tychè et pronoia. La marche du monde selon Plutarque. Coimbra e Paris, 183-194.

Leão, D. F. (2012), "Polites, idiotes, kosmopolites: a Atenas de Fócion”, in D. F. Leão, A globalização no Mundo Antigo. Do polites ao kosmopolites. Coimbra, 85-96.

Leão, D. F. (2016a), "Consistency and Criticism in Plutarch's Writings Concerning the Laws of Solon", in J. Opsomer, G. Roskam \& F. B. Titchener (eds.), A Versatile Gentleman. Consistency in Plutarch's Writing. Leuven, 243-254.

Leão, D. F. (2016b), "Politeuma in Plutarch", Synthesis 23: 87-99.

Leão, D. F. (2018), "Plutarch on Demetrius of Phalerum: the Intellectual, the Legislator and the Expatriate", in G. Thür, U. Yiftach \& R. Zelnick-Abramovitz (herausg.) Symposion 2017. Wien, [pp. no prelo]

Leão, D. F. \& Rhodes, P. J. (2015), The Laws of Solon. A New Edition with Introduction, Translation and Commentary. London.

Muccioli, F. (2015), "Alle soglie del ruler cult: Atene nell'età di Demetrio del Falero", Erga-Logoi 3.1: 7-46.

O'Sullivan, L. (2009), The Regime of Demetrius of Phalerum in Athens, 317-307 BCE. A Philosopher in Politics. Leiden.

Sollenberger, M. G. (2000), “Diogenes Laertius' Life of Demetrius of Phalerum”, in W. W. Fortenbaugh \& E. Schütrumpf, Demetrius of Phalerum. Text, Translation and Discussion. Rutgers University Studies in Classical Humamities, vol. IX. New Brunswick, 311-329.

Stadter, P. A. (1989), A Commentary on Plutarch's Pericles. Chapel Hill.

Tracy, S. V. (2000), "Demetrius of Phalerum: Who Was He and Who Was He Not?", in W. W. Fortenbaugh \& E. Schütrumpf, Demetrius of Phalerum. Text, Translation and Discussion. Rutgers University Studies in Classical Humamities, vol. IX. New Brunswick, 331-345.

Trapp, Michael B. (1999), "Socrates, the Phaedo, and the Lives of Phocion and Cato the Younger", in A. Pérez Jiménez, J. García López \& R. María Aguilar (eds.), Plutarco, Platón y Aristóteles. Madrid, 487-499.

Várzeas, M. (2012), Plutarco. Vidas Paralelas: Demóstenes e Cícero. Tradução do Grego, introdução e notas. Coimbra.

Wilson, P. \& Csapo, E. (2012), "From chorêgia to agônothesia: Evidence for the Administration and Finance of the Athenian Theatre in the Late Fourth Century BC", in D. Rosenbloom \& J. Davidson (eds.), Greek Drama IV: Texts, Contexts, Performance. Oxford, 300-321. 